\title{
The "new great game" in the south caucasus: competition for power and influence
}

\section{Khayal Iskandarov ${ }^{A}$; Piotr Gawliczek ${ }^{\mathrm{B}}$}

Received: December 20, 2019 | Revised: February 1, 2020 | Accepted: February 29, 2020

DOI: $10.33445 /$ sds.2020.10.1.4

\begin{abstract}
The South Caucasus has always been a playground of different rivals throughout centuries. Each rival endeavors to impose its rules and tries to capitalize on the geostrategic benefits of the region. The paper studies the rivalry of geostrategies in the South Caucasus region. The attitude of every external actor engaged in the region has been delineated. Their vested interests have been brought into focus and their influence has been relatively juxtposed with each other. The issue of energy transportation through the South Caucasus region is considered as a central element of clashing interests of the external actors. The authors attempted to compare the ongoing processes taking place in the South Caucasus with an "Old Great Game" and justify the presence of "New Great Game". The recommendations have been made for the countries in the region to avoid the issues which are politically detrimental to their national security.
\end{abstract}

Keywords: "New Great Game", "Old Great Game", South Caucasus, competition, confrontation.

\section{Introduction}

There are many different approaches and theoretical lenses with which to study international relations and to make sense of events, trends and processes. Although such established theoretical lenses as realism, constructivism, Marxism, feminism and others exist, neo-liberalism has been chosen as the means to make sense of this case study. Liberalism concerns the expansion of its zone of influence, which in the context of this article is likely to bring it into competition or conflict as Russia views the region as a zone of its interests and influence [8].

As a theoretical approach to international relations, neo-liberalism draws upon the concepts of rationality and contracting, focusing attention on the central role played by institutions and organisations in the sphere of international politics. These organisations constantly balance political interests and act as a balance between rule-based interaction and the unconstrained exercise of political power. One of the original criticisms of neo-liberalism was by neo-realists with the claim that they underestimated the role of domestic politics in international politics and cooperation. This has since come to be accepted by the neo-liberal camp. Attention focuses upon the issue of influence within international institutionalised settings of rules versus power. Neo-liberals approach institutions from a contractual perspective where they are used as "solutions" to a given collective-action problem. Therefore, logically an institution begins the process by identifying and highlighting a strategic problem that needs to be addressed and communicates it. How does the competition for power and influence in regions manifest itself [8]?

Comparative analysis, synthesis, inductive and deductive methods have been used in the paper to come up with conclusive outcomes.

\footnotetext{
A War College of the Armed Forces, Republic of Azerbaijan.e-mail: xayal1333@gmail.com.

${ }^{B}$ University of Warmia and Mazury, Poland, Assoc. Prof., Ph.D. e-mail: pgawliczek@gmail.com. ORCID: 0000-00020462-1168
} 


\section{Results and discussion}

\section{Competition for power and influence in regions and the "Old Great Game"}

Throughout the nineteenth century, British governments were worried by the continuous expansion of the Russian empire towards Central Eurasia. As soon as czarist armies overran Central Asia, attention shifted to Persia, to Afghanistan in the Indian Continent and to the mountain passes of the Himalayas. By the last quarter of the nineteenth century, there was a conventional wisdom that the next inevitable war - Great War was going to be the final showdown between Britain and Russia [14].

For 100 years Russia had been expanding east and south at a rate, it had been estimated, of 55 square miles a day. Even though the process seemed inexorable, Britain was determined to stop it before the British Indian Empire was threatened. The rivalry between the two, entitled "The Great Game" in the British Press, ranged from Europe to the Far East. It led Britain into largely unnecessary and at times disastrous military adventure in both Afghanistan and Tibet, which Russia never really intended to invade [14].

The British Lord Ellenborough started "The Great Game" on January 12, 1830, with an edict establishing a new trade route from India to Bukhara, using Turkey, Persia, and Afghanistan as a buffer against Russia to prevent it from controlling any ports on the Persian Gulf. Meanwhile, Russia wanted to establish a neutral zone in Afghanistan allowing for their use of crucial trade routes [4].

The British intelligence officer Arthur Conolly was probably the first who called the Russo-British rivalry "Great Game" in 1830s; whilst Rudyard Kipling's novel "Kim" published in 1901 brought this term to fame [17].

The Great Game comprised of three phases. In the first phase, the methods used were those of secret agents, coupled with overt military action upon occasion. This phase of the Great Game ended in 1907 with the signing of the AngloRussian Convention. In the second phase ("Drang nach Osten" undertaken by Wilhelmine Germany) the operational methods - secret agents attempting to manipulate local tribes and peoples were the same as in the first phase, as was the aim. Following the 1917 Russian Revolution when the Bolsheviks under Lenin set out, the third phase kicked off "by means of armed uprisings, to liberate the whole of Asia from imperialist domination". The eventual result of this third round was the consolidation of Bolshevik power over the old Tsarist domains [9].

The resurgence of Great Game took place with diversified objectives, strategies, players and interests after a hundred years of period with the centrality of the energy reserves of the Central Asia as well as Caspian Basins [12]. However, some see the contemporary analogies of the Great Game term as being over used and even are in some instances misleading. The original $19^{\text {th }}$ century Great Game concerned classic imperialism and territorial annexation. Whereas there is a significant difference in the practice of the New Great Game, which has become "shorthand" for competition in influence, profit, power and hegemony. In order to answer the question of a New Great Game exists or not, it is necessary to begin looking at the specifics of the South Caucasus, before moving on to the actions and motivations driving global and regional actors [8].

Can these set of goals and circumstances of the $19^{\text {th }}$ century be used as an accurate analogy for what is currently happening?

The factors stipulating "New Great Game" in the South Caucasus

There have been different academic arguments both for and against the proposition that there is currently a New Great Game underway in the South Caucasus. First, let us summarise the changes to the environment that potentially could support a "New Great Game". Trenin states that Russia's North and South Caucasus policy centred upon the goal of suppressing the insurgency in Chechnya, which was considered as being largely fulfilled in 2004. All other issues were treated as being of secondary or tertiary importance [7]. There was a shift in goals after Chechnya was largely pacified, which centred on resisting the 
spread of Western and US influence in the Commonwealth of Independent States. "From this perspective, Armenia featured as Russia's regional bulwark and security base; Georgia, a pro-US implantation within Russia's sphere; and Azerbaijan, a nominally neutral battleground in Russian-US competition" [7]. This situation sets the scene for continued competition for influence in the region based especially on energy issues and geopolitical spheres. The Old Great Game involved the attempt to limit the territorial expansion and influence of one Empire, which was seen as a direct threat to the other Empire [8].

As early as 1994-1995, there were some scholars that had begun to suggest that a New Great Game had begun. The logic of this New Great Game was brought about by the collapse of the Soviet Union resulting in a security and influence vacuum, which meant that a lot of 'new' territory was opened up to possible external actors. However, there was some caution in applying an absolute blanket use of the analogy to the whole picture as there were regional variations and differences appearing in the CIS. One of the differences noted was in the original Great Game there was less attention paid to the local elites, beyond using them as figureheads and proxies in the rivalry. The New Great Game continues to try and manipulate the local elites; however, the local populations have a much more pronounced sense of self-identity (even if it is not a coherent national one) [7]. Other differences and nuances were also observed:

- the original Great Game not only involved armies, but also European adventurers, seeking to penetrate and control previously unexplored territory;

- process was not only driven by aspirations for territorial expansion and military advantage, but a strong desire to open up new trade and markets. Therefore not only diplomatic manoeuvre, but commercial penetration. In the New Great Game, aid is disguised as investment and is a means to have a say in regional affairs, where trade is a lever of economic reward or coercion;

- the Old Great Game involved two rival powers with a parallel but non-contiguous border expanding towards each other over what was considered as being no-man's land. The New Great Game involves Russia seeking to maintain influence against Western powers in order to retain a buffer zone [7].

These observations reveal some distinct subtleties that exist between the Old and New Great Game, and how the power rivalry was conceived and waged. Cuthbertson makes the additional observation that concerns the variation of how the New Great Game is managed. "If Moscow's policies in the Baltic States reveal Russian behaviour at its most subtle, Russian power is at its most naked and abusive in the Transcaucasus. Here Russia plays the new Great Game with all the panache, flair, and ruthlessness that it displayed in acquiring its empire in the $19^{\text {th }}$ century" [7]. Other scholars have made observations that in part coincide with Cuthbertson. There are a number of constraints and restraints on the states of the South Caucasus, both historical and contemporary, which limit their freedom of action. Anderson notes that the region has become a classic buffer zone, with some parallels to the original Great Game where powerful states have delimited the region for their own purposes. "Thus, as a buffer zone, there is an ever-present danger of fragmentation and either collaboration with or more likely subservience to a regional or outside power" [8]. Some other scholars and commentators see the analogy as being overblown.

According to some researchers, in the bigger strategic picture an observable competition for power and influence in the South Caucasus by foreign powers, especially NATO and Russia is clearly observable, Having brought the RussianGeorgian war and Ukraine crisis to the fore, the authors claim that it is a place where the actions of the other side are perceived as being equally provocative even if these processes and events occur beyond the region [7].

The contrast between the original Great Game and the new Great Game in terms of the actors involved is one of the most striking differences in concept. In the $19^{\text {th }}$ century the Great Game was played by two Imperial powers, the British and Russian empires. The New Great Game contrasts to this, with the type and numbers of actors 
involved in the game having transformed and grown [9]. Today regional and global powers like, Russia, Iran, Turkey and the United States, organizations like the European Union, NATO and CSTO do not hide their vested interest in this region [8]. Three new states in the South Caucasus, each with their own aims, objectives and methods, have radically transformed the concept of a New Great Game [9]. Though the external actors involved are diverse, their objectives are all the same - geopolitical dominance and maximisation of profits.

The South Caucasus is a complicated region of interdependent relations over governance and affiliation, security and conflict, trade and energy. Current tensions between West and Russia expose the region to jeopardy and affects the domestic affairs. The risk of Russian intervention in Georgia if it further integrates into Euro-Atlantic structures remains present and the risk of escalation of the conflict in Nagorno-Karabakh remains alarming [3].

The South Caucasus region is a vast transitional conduit, abundant in energy reserves, and has became an area of clashing interests since the collapse of the USSR. It has a potential to be more significant area of opportunities, if its stability is ideally ensured. The main goal in the geopolitics of the South Caucasus is the control of the transportation of oil and gas. For some, this is about energy perse (China), for others, mostly about the economic implications (the countries in the region and to some extent Turkey and Iran, and the oil companies); to others again it is mainly a way to gain influence and/or prevent others from doing so (the USA and Russia, in particular). The struggle is basically about the politics and economics of competing pipeline projects to connect the Caspian Basin hydrocarbon resources to world markets, via Russia and the Black Sea, via the South Caucasus and Turkey, via Iran, Afghanistan, or Kazakhstan to China [11].

Anatol Lieven downplays the Great Game analogy because "the importance of the Caspian region to American foreign policy is grossly exaggerated" [7]. It was only the demise of the Soviet Union that permitted the occasion to become engaged in the region. A number of factors in the mid-1990s influenced a change in the US approach, such as the oil and gas reserves in the region, deterioration in relations between the US and Russia, a growing instability in Russia, and strengthening ties between the US and Turkey. The result of these factors "was an ambitious strategy of attempting to "roll back" Russian influence in the region and to replace it with a new, more benign American hegemony" [7]. Other scholars have also noted that the collapse of the Soviet Union in 1991 also permitted the possibility of the US and Western Europe to gain access to energy reserves, which had been forecast as being enormous [7]. What Lieven saw was not a clash of armies and diplomats to divide and occupy territory for economic and military advantage, but rather an attempt to "conquer" countries through imparting norms and values to make them more like the US and thereby gain geopolitical and geo-economic advantage through influence [8].

One could say that the Great Game simply reflected something natural, something that is emanating from the essence of the geographical space. However, this essence is not natural or everlasting, but is created by the people who firstly perceive and imagine and then act. Indeed, the Russians and the British had different imaginations and acted according to different strategies and geopolitical conceptions. These conceptions had been formulated at the very end of the Great Game (1890 and 1904 respectively), but both powers had obviously acted according to those codes [17].

\section{External engagement in the South Caucasus}

External actors (countries or organisations) play a crucial role in shaping events in the South Caucasus; often not by meeting their own policy objectives but by blocking the policies of other actors [3]. It would be relevant to elaborate on each and every actor involved in the region.

The United States wants to see the South Caucasus as a Western-oriented region. At a conference titled "Twenty years of independence in the South Caucasus: achievements and challenges" held in Washington in September 2011, Jennifer Walsh, Principal Director for Russia, Ukraine, and Eurasia, Department of Defense 
explained the reasons for the importance of the South Caucasus for the US:

1. It has an important geographical location.

2. It is a transit of the supply of troops in Afghanistan.

3. It plays a crucial role in the European energy security.

4. The stability of the region and the settlement of the conflicts are in the interest of the United States.

5. The United States considers the region as a part of Europe and is interested in joining the countries to European institutions [8].

Through the Eastern Partnership (EaP) program, the EU has become a major investor and actor in the South Caucasus countries. It is the largest donor to the region. The EU is also the largest trade partner of all three countries. The aim is to to promote stability and development in the region and forge closer ties [3]. However, the ever-increasing need for the diversification of energy sources and cooperation in energy transit issues has, perhaps, made the West attach a great deal of importance to the South Caucasus region (Azerbaijan-Georgia-Turkey corridor) as a reliable transit route avoiding Russian and Iranian territories [1]. Nonetheless, Brussels' clout in the South Caucasus remains modest. The difference between Europe's expressed interests and what it actually can achieve remains substantial, mostly due to the lack of a hard security component and limited political interest. This is shown by the EU's lack of involvement and influence in helping to resolve the region's protracted conflicts or presenting a reliable counterweight to Russia's hard security influence. EU soft power has little bearing on settling the Abkhazia or South Ossetia conflicts in Georgia or the Nagorno-Karabakh conflict between Armenia and Azerbaijan [3]. However, Russia perceives the West as an utterly direct threat to Russian national security. Even though, the European Union does not have any institution of any resemblance to a common military force, its expansion is a political one [13].

Turkey, the staunch ally and the linchpin of NATO in Central Asia and the Caucasus during the Cold War era could have lost its exclusive status with the demise of the Soviet Union. To remain an indispensable partner of the West as an intermediary between the Soviet successor-states in the region and the Euro-Atlantic institutions, Ankara needed close ties with the newly independent states in the Caucasus and Central Asia. Turkey gives primacy to relations with Azerbaijan, both because of the close cultural and linguistic affinities between the two states, and because of Azerbaijan's pivotal geopolitical position. Turkey has unflinchingly supported Azerbaijan since the latter gained its independence. It maintains close relations with Georgia as well. Turkey is the driving force behind most of the regional cooperation projects with the contribution of Azerbaijan. The initiation of strategic projects such as Baku-Tbilisi-Ceyhan (BTC) crude oil and Baku-Tbilisi-Erzurum (BTE) natural gas pipelines, Baku-Tbilisi-Kars (BTK) railway are milestones of this cooperation [8]. Following the realization of the BTC, main export pipeline, Azerbaijan's new Southern Gas Corridor (SGC) project was generated. The Trans-Anatolian Pipeline (TANAP) and its follow-up Trans-Adriatic Pipeline (TAP) are one of the main parts of the SGC, transporting the natural gas from the Shah Deniz-2 to the West. These pipelines enable the export of natural gas from the Middle East to Europe, along with the Caspian basin. Seven countries are involved in the implementation of the SGC: Azerbaijan, Georgia, Turkey, Bulgaria, Greece, Albania and Italy. In the future, the three Balkan countries may also join the SGC. The SGC is one of the priority projects for the EU and 10 billion cubic meters of Azerbaijani gas is estimated to be transported from the Caspian region to the West through Georgia and Turkey. The first gas through the Southern Gas Corridor was delivered to Turkey on June 12, 2018 and to Greece on June 15, 2019. Turkey and Azerbaijan formally marked the completion of TANAP on November 30, 2019, a milestone in a major project to help reduce Europe's dependence on Russian gas. TANAP crosses the breadth of Turkey, east to west, and could transport up to 16 billion cubic meters $(\mathrm{bcm})$ of Azeri gas a year. Europe is allocated $10 \mathrm{bcm}$, with $6 \mathrm{bcm}$ earmarked for the Turkish market. Capacity could be increased to $31 \mathrm{bcm}$ with additional investment [16]. It is difficult to imagine how these energy projects could have been realized without Turkey's active support. These 
projects, and the prospects of expanding the EastWest energy corridor, are considered key to improving Turkey's energy security. Turkey is heavily dependent on Russia for its energy supply [5]. Therefore, Ankara is interested in diversifying its energy sources and the South Caucasus provides the best alternative to benefit from the resources of the Caspian basin. Armenia is only country in the region, which is ostracized for its unconstructive attitude. Turkey and Azerbaijan have no diplomatic relations with Armenia to the detriment of the latter's economic circumstances [8]. That is a major challenge for Turkey. Because it is hindered from playing a more effective role in encouraging greater stability and prosperity in the region. There were two attempts to normalize relations between the two countries, one in the early 1990s following Armenia's independence and another in 2009, but neither has borne fruit [5]. The failure to reach this agreement underscored Turkey's limited ability to project itself in the South Caucasus, and Russia's greater potential to undermine Turkey's efforts if they were not deemed mutually advantageous. Currently, the prospects of opening the border and normalizing relations between the two sides is not very promising [5].

There is a significant overlap of interests regarding the region between the EU, Turkey and the US. Thus, the Western strategy for the region is oriented towards the fulfillment of these primary strategic objectives of the West [11]:

- keep the flow of oil and gas from Central Asia and the Caspian Sea to the USA and Europe permanent and unobstructed;

- build an infrastructure of pipelines that would completely skirt Russia (and Iran), and open up the Central Asian energy reserves to the world markets, reducing the possibility of obstruction and blockade of pipelines that Russia could impose;

- keep Russian and Chinese influence as weak and distant as possible. This is a very difficult task now, and in the future, it will not be much easier;

- reduce security challenges (terrorism, drug trafficking, and proliferation of weapons of mass destruction) to the most minimal possible level.
The South Caucasus is also in the national interest of Russia with its geopolitical and strategic importance. As the former "ruler" and most powerful state in the post-Soviet area, Russia remains a fundamental actor, claiming the postSoviet space in its main foreign policy documents. Russia is very much engaged in the South Caucasus, despite not having unlimited influence there, but still retains substantial leverage and has been reasserting its influence in the area. Moscow has a military-strategic, economic (especially in energy field), as well as domestic and political leverage over the region. All three countries remain closely connected to the Russian economy through infrastructure, trade, investment, and remittances from permanent diaspora populations and migrant workers [8]. Russia has historically close ties with the South Caucasus and opposes the interference of other countries in regional affairs and considers NATO's expansion towards the South Caucasus as a threat to its security. As Vladimir Degoyev, the Russian researcher mentioned: "The West should realize that Russia has a vital interest in the South Caucasus. Russia and the West's goals in the region are basically the same. But there is a paradox that if NATO is Russia's neighbor in the South Caucasus, there will never be peace in this region". Therefore, some Russian political circles try to prevent the South Caucasus-NATO cooperation through various means. Russia has been exerting itself in order to incorporate all South Caucasus countries into both the CSTO and EEU due to its geostrategic location and natural resources. It wants to recreate the erstwhile world order in which Moscow again plays a major role, and it's strategy is to cultivate fear of Russia (as it has been Russia's historical culture) to force submission from their rivals [8]. Unlike the US/EU approach of trying to change the values and norms of the region, which is potentially a threat to the political and economic elites of the region, Russia applies a regime stability approach. The result is the more the West attempts to 'democratise' the region, the more likely the regimes in the region will pivot to powers such as Russia and China driven by the instinct of regime survival [7]. "In this Great Power rivalry, Russia has at present 
tactically outmanoeuvred NATO in the Caucasus and made it virtually untenable for the alliance to maintain a permanent presence in the region, despite strong efforts by the US and Turkey" [7]. Markedonov notes that the rising tensions between the US-led West and Russia globally are mirrored in the South Caucasus where there is the risk of more disagreements and that even a possibility of a conflict cannot be completely ruled out [7].

Another country that closely monitors the region is Iran. The independence of the South Caucasian states took Iran by surprise, especially as the war between Azerbaijan and Armenia revealed deep contradictions in the foreign policy of the Islamic Republic. Disagreements within the ruling circles in Tehran have ensured a certain level of mixed signals, but in spite of these differences, Iranian policy has proven remarkably durable. Three main facets have characterized Iranian policy. Firstly, a concern over the emergence of the independent state of Azerbaijan, leading to a gradual tilt towards Armenia in the ArmenianAzerbaijani conflict. Secondly, a dramatic improvement in relations with Russia that, despite a shaky basis, have developed into a strategic partnership. Thirdly, an increasing desire to influence the development of oil and gas resources in the Caspian Sea, seeking to avoid Turkish influence over pipeline routes. Iran, in its turn, does not want the participation of nonregional powers in the processes in the South Caucasus and considers the " $3+3$ " model that considers the engagement of only three countries: Turkey, Russia and Iran [8]. However, Iran's role for the foreseeable future in the South Caucasus is unclear. It seems unlikely that Tehran will become a substantial factor in the near term as energy infrastructure (if agreed on and built) will take many years to come into being [3].

China is foremost an economic actor in the South Caucasus. Trade levels have steadily risen over the last decade; China is now the third or fourth trade partner of South Caucasus states. China's Silk Road Economic Belt programme is meant to revive the Silk Road trade land route from China through Central Asia and the Caucasus to the Middle East and Europe [3]. However, the importance of the South Caucasus countries within this programme is not same. Armenia has less potential for the initiative. It does not have enough transportation infrastructure and its borders with Azerbaijan and Turkey closed [10]. China considers the region as a transit route to Europe as well as an interesting region for investments; a market for its products; and a potential source of Azerbaijani energy. China is a visible geopolitical actor in Central Asia (primarily through trade and investment), and sees the South Caucasus as a transit route and as the "neighbours of the neighbours" - similar to the EU's perception of Central Asia. From this standpoint, China is interested in stability in the Caucasus in order to ensure an open corridor to Europe but is not directly concerned with the region. Second, Beijing does not wish to step on Moscow's toes in the South Caucasus, while relations between the two countries feature a mix of competition and partnership (via the Shanghai Cooperation Organisation) in Central Asia. Third, China has not taken sides on conflict issues and it has built economic ties with all three countries in the region. China does not play an important role in the domestic affairs of the South Caucasus, as do Russia and the EU [3]. Therefore, it does not jeopardize Russian dominance in the region. Because its influence is not accompanied by a political and military presence unlike the West. However, regardless of how regional dynamics play out in the coming years, China's growing presence in the South Caucasus is a factor that can no longer be ignored. It may not receive the same level of consideration in the media or in policy circles that the traditional interplay between Russia and the West in the region [15]. According to Ishik Bora, even though China genuinely does not seek to be militarily present in the region and endeavours to improve commercial ties, it could come to a position where it might appear to be the strongest candidate to balance Russia in the South Caucasus [13].

NATO is interested in the Caucasus as a strategically important energy market, a lucrative traffic artery with access to the Caspian Sea and Central Asia, and a region bordering with Iran. The Alliance's orientation towards Eastern Europe and Euroasia may explain NATO Secretary General Javier Solana's February 1997 statement that 
"Europe will not be completely secure if the countries of the Caucasus remain outside European security" [8]. Moreover, Brussels takes stock of Russia's intensified activities in the region, but tends to overlook Moscow's actions on deescalating ongoing conflicts and, instead, focuses on the threat of Russia establishing its hegemony over the post-soviet space [8]. In this context, the famous American diplomat and expert Ronald Asmus' assessment of the five day war of 2008 (The Russian-Georgian war) is significant. He believes that the conflict "was not fought over territory, minority rights or the future status of the separatist provinces Abkhazia and South Ossetia... The root cause of this war was geopolitical. Georgia was determined to go to the West and Russia was determined to stop it from doing so" [8]. Considering the strategic nature of the region, NATO should keep a close eye on developments in the South Caucasus, both politically and economically. In addition, Russia has shown that it uses the frozen conflicts and energy as tools in order to push NATO away from its borders and to weaken its cohesion. If we consider all non-NATO countries on the European periphery of Russia, we would see that only Finland, Sweden and Belarus do not have any conflicts in their territories. The first two are neutral countries and the latter is a CSTO member. What we can deduce from this is that NATO membership for aspiring countries has become illusory, even wishful thinking for the foreseeable future. However, it does not mean that NATO should stay on the sidelines on the issue of the conflicts, because their continued existence is an important concern for overall European security [1].

The overt use of "power" within the New Great Game has been more restrained, though this is difficult to quantify. No longer is it acceptable to use naked, dominating aggressive power in the international system. While there are still some demonstrations of force, the degree to which force can be used without acceptable justification has diminished in the years between the two games. In the international system, the original game was conducted as a direct competition between the two powers with no other interference brooked, or indeed possible [9].

\section{Conclusions}

The historical analysis of the processes taken place in the South Caucasus after the demise of the USSR proves that "New Great Game" has already started and continues today, with different actors, however, with the same purpose. The South Caucasus is one of the primary regions where the external actors flex their muscles, sap each other's strength. Regional and global actors like Russia, Turkey, Iran, China and the US, leading organizations like EU, NATO, EEU and CSTO are the actors involved in this struggle. Russia is the most assertive one amongst all players, which has a capacity to meddle in domestic affairs of the countries in the region. The US/EU approach of trying to change the values and norms of the region is perceived as provocative by Moscow. China has economically engaged, refraing itself from associating with political issues. Nonetheless, its potential for future processes can not be ignored. Iran is enthusiastic to be represented in regional processes and tries to exclude other external actors, highlighting $3+3$ model. Turkey does not have as strong clouts as Russia has, however, its presence offsets Iran's dominance. The only way for the South Caucasus countries to eradicate their existing problems is to strike the right balance between external (global and regional) actors, of course based on the principle of reciprocity. Multipolarity is a key to this kind of foreign policy. This strategy will reduce the on-going tension between Russia and the West regarding the region. It will appease the growing hysteria in Iran. Europe is vulnerable to energy coercion and Azerbaijan-Georgia-Turkey tandem offers it the best option to withstand this coercion and have an access to the natural resources of the Central Asian countries. Maintaining security in the region is in the interest of energy-importing, transit and energyexporting countries, which need to ensure the security of their industry and pipeline 
infrastructure. This in its turn necessitates the close cooperation between the West and South Caucasus countries [6]. NATO provides the best tools to enable the regional countries to boost their security and an option of multipolarity does not rule out close cooperation with the
Alliance [2]. The "New Great Game" seems to be inexorable, and its negative impact is inevitable, however it is possible to get through the ongoing rivalry with minor political damage in case the proposed strategy is adopted.

\section{References}

1. Elman Nasirov, Khayal Iskandarov, Sadi Sadiyev. "The South Caucasus: A Playground between NATO and Russia?" Connections QJ 16, no. 3 (2017): 47-56.

2. Piotr Gawliczek, "Innovative ICT solutions and/with/for changing security environment. Case study - NATO DEEP ADL Portal and Social Media, Social development and Security, (Vol. 9, No. 4, 2019): 111-119. https://doi.org/10.33445/sds.2019.9.4.8

3. Jos Boonstra, "The South Caucasus and its Wider Neighbourhood", Working paper, funded by the European Union's Seventh Framework Programme (FP7/2007-2013) under grant agreement $n^{\circ} 613354-C A S C A D E$ Project, FMSH, Paris, December 2015.

4. Kallie Szczepanski, "What Was the Great Game?" July 31, 2019, https://bit.ly/35ycrtl.

5. Kemal Kirişci, Andrew Moffatt, "Turkey and the South Caucasus: An Opportunity for Soft Regionalism?" Regional Security Issues (2015): 67-88.

6. Khayal Iskandarov, Piotr Gawliczek, "The south Caucasus and NATO's defence education enhancement programme. Retrospective analysis", Social development and Security, (Vol. 9, No. 5, 2019): 3-14. https://doi.org/10.33445/sds.2019.9.5.1

7. Khayal Iskandarov, Gregory Simons, Piotr Gawliczek. "Russia and NATO in the South Caucasus: A Playground for a "New Great Game", Connections QJ, 2019 (in press).

8. Khayal Iskandarov, The South Caucasus-NATO cooperation, Riga: Lambert Academic Publishing, 2019.
9. Matthew Edward, "The New Great Game and the new great gamers: Disciples of Kipling and Mackinder", Central Asian Survey 22(1), (March, 2003): 83-102.

10. Orkhan Baghirov, "China's changing interests in South Caucasus", May 12, 2019, https://bit.ly/2PYcliC.

11. Petar Kurečić, "The New Great Game: Rivalry of Geostrategies and Geoeconomies in Central Asia", Hrvatski Geografski Glasnik, 72/1 (2010): 21-48.

12. Qamar Fatima, Sumera Zafar, "New Great Game: Players, Interests, Strategies and Central Asia", A Research Journal of South Asian Studies, Vol. 29, No.2 (July - December 2014): 623-652.

13. Işik Bora S., "China's growing presence in the Caucasus", Commentary No: 2017/83, 01.11.2017, https://bit.ly/2PvxfMD.

14. Sreenivasarao Vepachedu, "The CenturiesOld Great Game", 27 March, 2018, https://bit.ly/2RYOMAl.

15. Tony Rinna, "The South Caucasus and China's Rising Presence", 03 December 2015, https://bit.ly/2ELx3mt.

16. "Turkey and Azerbaijan mark completion of TANAP pipeline to take gas to Europe", November 30, 2019, https://reut.rs/361NIOf.

17. Vincenc Kopeček, "Russian Geopolitical Perceptions and Imaginations of the SouthCaucasus." In Beyond Globalisation: Exploring the Limits of Globalisation in the Regional Context (conference proceedings), 99-105. Ostrava: University of Ostrava Czech Republic, 2010. 